Вітаємо ювіляра

\title{
К 70-летию профессора Валерия Дмитриевича Работягова
}

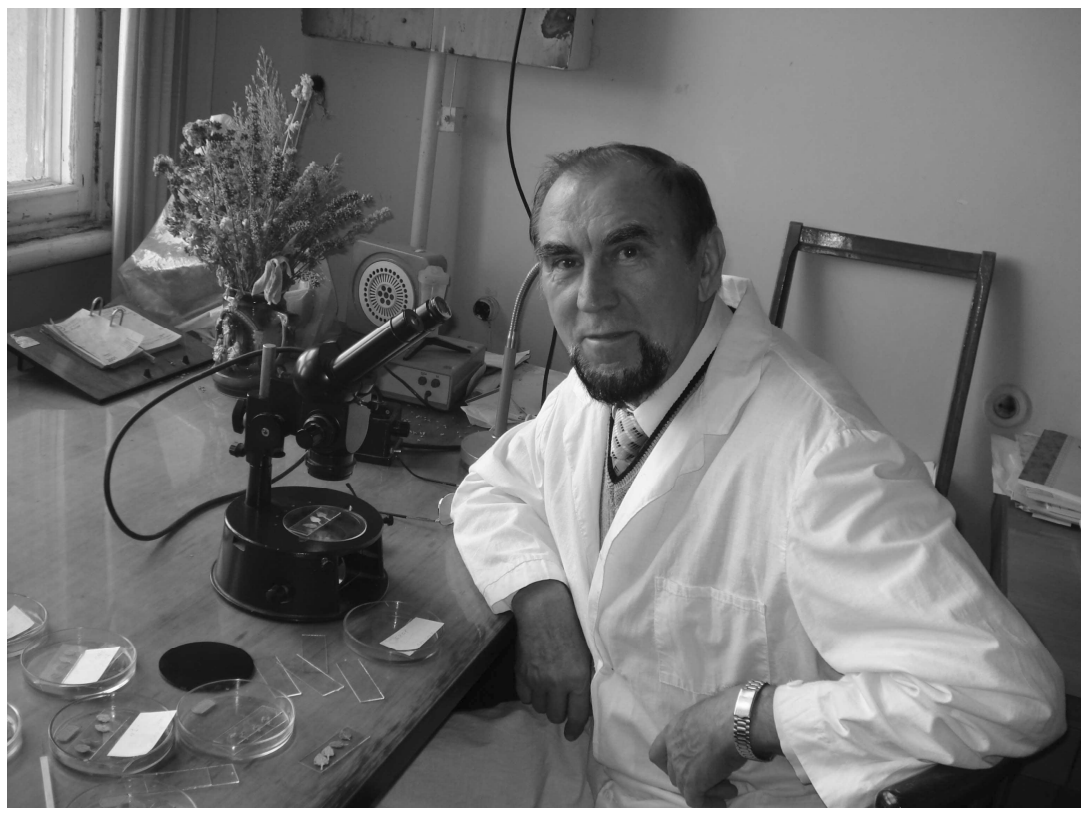

13 июля 2010 года исполнилось 70 лет со дня рождения известного ученого-ботаника, одного из членов редакционной коллегии «Черноморского ботанического журнала», главного научного сотрудника отдела новых ароматических и лекарственных культур Никитского ботанического сада - Национального научного центра, доктора биологических наук, профессора Валерия Дмитриевича Работягова.

Свой творческий путь в Никитском ботаническом саду Валерий Дмитриевич начал в 1965 году, поступивши на работу на должность садовника. В 1968 году прослушал курсы повышения квалификации при Московском государственном университете по специальности «генетика растений». С 1969 по 1972 год обучался в аспирантуре, представивши в срок, и вскорости, защитил кандидатскую диссертацию на тему: «Экспериментальная полиплоидия у лаванды настоящей».

С 1972 по 1983 года - младший научный сотрудник, а с 1983 года - старший научный сотрудник отдела цитогенетики и эмбриологии растений Государственного Никитского ботанического сада. В процессе творческой деятельности Валерий Дмитриевич разрабатывал ряд тем связанных с генетикой и селекцией, которые имеют теоретическое и практическое применение в селекционном процессе эфиромасличных культур. Им разработаны вопросы синтетического создания гибридных генотипов растений с разным числом геномов и в различных сочетаниях в родах Lavandula L., Nepeta L., Thymus L. Впервые была преодолена стерильность у лавандина и синтезировано 15 новых форм.

В настоящее время Валерием Дмитриевичем разрабатываются эффективные генетические и цитогенетические методы создания, отбора и оценки новых сортов эфиромасличных культур. Эти исследования предполагают получение полиплоидов и анеуплоидных форм, изучение закономерностей изменчивости хозяйственно-ценных признаков при межвидовом скрещивании. Экспериментально доказана перспективность использования комплекса генетических методов - межвидовой гибридизации, полиплоидии, имбридинга - для выведения новых высокопродуктивных сортов эфиромасличных культур.

Докторская диссертация Валерия Дмитриевича Работягова «Экспериментальное формообразование и интродукция лаванды», защищенная в 1991 году, посвящена проблемам формообразования и созданию принципиально нового исходного материала методами межвидовой гибридизации и экспериментальной полиплоидии, и изучению основных закономерностей изменчивости и наследования биохимических и утилитарных признаков. 
Круг научных интересов Валерия Дмитриевича Работягова охватывает вопросы синтеза гибридных генотипов растений с разным числом хромосом у различных таксонов. Им впервые получены полиплоиды миндаля, инжира, хурмы, которые включены в генофонд этих культур. Среди научного наследия Валерия Дмитриевича следует отметить 5 монографий, 13 методических рекомендаций, 297 научных статей, 2 патента, 4 авторских свидетельства на изобретения и 19 авторских свидетельств на сорта эфиромасличных культур. Его научные труды пользуются спросом у отечественных и зарубежных специалистов США, Канады, Испании, Португалии, Франции, Болгарии.

Валерий Дмитриевич участвует в работе научных симпозиумов, конференций и совещаний, является высококвалифицированным специалистом, постоянно повышая свой научный уровень. В последние годы он овладел новейшими методами интрогрессии генетического материала одного вида в другой.

Очень много своего времени Валерий Дмитриевич отдает работе с научной молодежью. Под его руководством защитилось 7 аспирантов. Он неоднократно приглашался в различные ВУЗы юга Украины председателем экзаменационной государственной комиссии. Его преподавательская деятельность была отмечена присвоением в 2003 году научного звания профессора. За научные достижения он награжден Почетной грамотой Президиума Верховной Рады Автономной Республики Крым.

Валерий Дмитриевич является душой коллектива Никитского ботанического сада, активно участвует в его творческой и научной жизни, являясь членом Ученого совета, членом методической комиссии, членом специализированного совета по защите докторских диссертаций при Никитском ботаническом саде - Национальном научном центре, и конечно активным членом редакционной коллегии Черноморского ботанического журнала. Встречи с Валерием Дмитриевичем, его научные дискуссии, рассказы о жизни, а иногда и просто небылицы в кругу друзей, сохраняются в памяти надолго.

Желаем Вам, Валерий Дмитриевич, сохранять бодрость духа, новых научных взлетов, доброго здоровья и успехов во всех сферах вашей многогранной деятельности! 